\title{
O PAPEL DA TRADUÇÃO NOS CONTATOS LITERÁRIOS INTERNACIONAIS
}

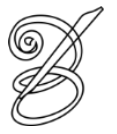 \\ Elena Beliakova \\ (Professora doutora da Universidade Federal da Cidade de Tcherepovets (Rússia), tradutora das obras de Jorge \\ Amado para o russo) \\ helena.belhakova@gmail.com
}

\begin{abstract}
Resumo: Tradução representa o papel principal em desenvolvimento dos contatos literários internacionais. A compreensão da dinâmica do desenvolvimento da literatura nacional não é possível sem a análise da literatura traduzida. A obra traduzida se inclui na literatura nacional apenas na forma da tradução. A tradução pode ser aceita ou não pelos motivos diferentes, mas ela passa por uma grande transformação no processo da percepção.
\end{abstract}

Palavras-chave: tradução, contatos literários, Jorge Amado.

Abstract: Translation plays a decisive part in the development of international literary contacts. Comprehension of the dynamics of the development of a national literature is impossible without consideration of foreign literature. A translated book enters into national literature only in the form of translation. A translated book may or may not be adopted by different reasons, but it undergoes serious transformations in the process of perception.

Keywords: translation, literary contacts, Jorge Amado.

$\mathrm{N}$ enhuma grande literatura pode desenvolver-se sem uma interação viva e criativa com outras literaturas. O estudo de relações internacionais da literatura é de extrema importância para a compreensão da identidade e da consciência dos processos subjacentes ao desenvolvimento das literaturas nacionais. A literatura de qualquer país é composta por dois elementos: a literatura nacional e a tradução. Nos tempos modernos, uma obra verdadeiramente significativa de qualquer literatura nacional se traduz em línguas estrangeiras e se torna, com todo o direito a isso, uma parte das literaturas de outros povos.

Portanto, só é possível compreender a complexa tela do desenvolvimento da literatura nacional à luz do processo literário mundial. Sem o estudo das relações internacionais da literatura, não é impossível traçar a dinâmica do desenvolvimento da literatura nacional, penetrar nos mecanismos de herança e substituição das suas tradições, ou na acumulação de seus valores artísticos.

A obra traduzida, de uma forma ou de outra, inevitavelmente se inclui no processo evolutivo da literatura nacional. Assim, o estudo das relações internacionais literárias supera as possíveis restrições da literatura nacional, tornando-se parte de um processo histórico- 
literário global. A obra traduzida se inclui assim no desenvolvimento das literaturas nacionais "como fenômeno de sua ideologia social, semelhante, em alguns aspectos, ao produto da criatividade nacional" (JIRMÚNSKI, 1981, p. 14).

Uma das mais importantes leis do relacionamento literário é o fato de que a literatura de língua estrangeira tem um impacto sobre outras literaturas apenas na forma da tradução. As funções inerentes às fontes externas, conhecidas em outro país apenas no idioma original, de modo geral, não saem das ligações desses contatos externos. Enquanto o texto estrangeiro "não fala na língua do país que o adotou, continua a representar um papel de exploração passiva" (STÁDNIKOV, 2000, p. 273).

Ou seja, esse texto estrangeiro pode conseguir fama suficiente entre uma parte dos leitores, e a crítica pode discutir o assunto, mas não pode entrar num processo literário alheio. A assimilação criativa ocorre somente depois da tradução ou das traduções, naturalmente, no caso de o texto passar a receber referências na cultura do outro país.

Surge, porém, uma questão: em que circunstâncias o texto tem receptividade num ambiente cultural diferente, por que uma obra de literatura se torna um fato significativo da 100 literatura estrangeira e por que, em outros meios, não se observa um efeito de contrapartida, sobre o desenvolvimento da literatura do destinatário? Por um lado, depende da qualidade e da natureza da própria obra. A importância das obras da literatura nacional para a literatura mundial depende da profundidade, plenitude e viveza com que reflita a vida de seu povo e encarne o espírito nacional: "a obra da literatura estrangeira pode tornar-se global, se nela arde a vida de sua cultura e se tem o poder de expressá-la eficientemente" (NEUPOKÓEVA, 1976, p. 154).

Um exemplo marcante é a obra de Jorge Amado. Num artigo sobre o aniversário dos 70 anos de Jorge Amado, proeminente estudiosa soviética de sua arte, Vera Kuteischikova, explicou o fenômeno da popularidade de Jorge Amado: "Como uma tempestade tropical, desceu sobre nós naquele tempo a vida desconhecida de uma terra distante do Novo Mundo, cujas experiências e paixões nos deixaram, literalmente, de respiração cortada" (KUTEISCHIKOVA, 1982).

Por outro lado, a percepção dos produtos da tradução é causada por necessidades internas da literatura que a assimila. O famoso pesquisador russo Alexei Vesselóvski salientava que a adoção da literatura não implica "lugar vazio, mas um fluxo eterno, uma linha semelhante de pensamento, e formas semelhantes de fantasia" (VESSELÓVSKI, 1939, 16). Isso significa que os contatos verdadeiramente criativos entre as literaturas são realizados 
apenas sob a condição de que a literatura de acolhimento tenha pré-requisitos para a aprendizagem dos elementos ideológicos e estéticos estrangeiros. Por exemplo, os livros de Jorge Amado foram aceitos na Rússia com carinho e entraram organicamente no contexto da literatura russa graças a ter o povo russo encontrado neles aquilo que lhe é característico e querido: amor à liberdade, grandiosidade da alma, desapego.

A escolha das obras para a tradução não é o resultado de conhecimento ocasional de um novo livro, das preferências literárias do tradutor ou da moda literária. Essa escolha é sempre determinada pelas exigências ideológicas desta ou daquela parte da sociedade. Por exemplo, a primeira tradução de Jorge Amado para a língua russa (São Jorge dos Ilhéus) foi publicada só em 1948, porque correspondia às exigências ideológicas mais rígidas daquela época. Sendo membro do Comitê Central do Partido Comunista Brasileiro, redator-chefe do jornal do partido, Hoje, dirigente do Instituto de Relações Culturais com a URSS e membro permanente do Conselho Mundial da Paz, Jorge Amado tornou-se um destacado ativista não só do movimento comunista brasileiro, mas também do internacional. Por isso, Jorge Amado tornou-se persona grata para os dirigentes soviéticos e foi escolhido para tradução na Rússia.

Toda influência literária está relacionada com a transformação de obras tomadas de empréstimo, que inclui o seu refinamento e sua adaptação criativa às peculiaridades da vida e do caráter nacionais, numa dada fase do desenvolvimento social, assim como à tradição literária do país receptor.

Nesse sentido, podem-se apontar vários sinais de que as obras traduzidas tornaram-se parte da cultura do destinatário:

1. A obra traduzida é lida por motivos estéticos, não por considerações pragmáticas (por exemplo, a necessidade de fazer um exame da literatura estrangeira). Um grande papel representa a personalidade do tradutor. Tal fator subjetivo, de que resulte uma tradução ruim, pode criar obstáculos à percepção da obra estrangeira, apesar de suas premissas ideológicas e estéticas favoráveis.

2. O original e a tradução são diferentemente avaliados pelos leitores. Nesse contexto, é interessante comparar a percepção das obras de Jorge Amado no Brasil e na Rússia. Os livros mais queridos no Brasil são Capitães da areia e Gabriela. Os livros mais queridos dos russos são Dona Flor e seus dois maridos e Seara vermelha. Em Capitães da Areia, os brasileiros acham o que lhes falta na vida e na arte: o amor limpo e romântico. Em Gabriela, o primeiro livro que expressa o caráter nacional brasileiro em toda a sua plenitude, os brasileiros se veem a si mesmos. 
Agora, por que esses livros se tornaram os mais lidos na Rússia. Seara vermelha tornou-se extremamente popular entre os leitores soviéticos. Naquele tempo, na União Soviética não havia a noção de classificação segundo o volume de vendas. No entanto, a popularidade do livro, publicado em 1949 pela Editora de Literatura Estrangeira, se prova pelo fato de o romance ter sido reeditado em 1954 pela mesma editora e, em 1963, em Vólogda, com grande circulação. Mas o mais importante é que os volumes de Seara vermelha, disponíveis naquele momento nas bibliotecas de cada aldeia, foram os mais esfrangalhados entre os outros livros de Amado. Maltrapilhos e, muitas vezes, sem capa, esses livros eram um atestado vivo de que Amado fora aprovado pelos leitores soviéticos.

Qual o motivo dessa aceitação? Obviamente, para os leitores soviéticos daquela época, grande parte dos quais era originária do campo, os fatos descritos e os destinos dos heróis eram compreensíveis e próximos. E, mais ainda, as pessoas que sobreviveram à coletivização e à fome da década de 1930, vivendo em seguida os terríveis anos da guerra e da reconstrução das ruínas da guerra, acolhiam Seara vermelha como um livro sobre sua própria vida, sobre o destino delas, encontrando ali algo que não existia, e não poderia existir, na literatura 102 soviética dessa época.

Dona Flor é outro caso. Em 1954, participando do II Congresso dos Escritores Soviéticos, Amado disse que o principal defeito da literatura soviética era a falta de atenção para com os sentimentos humanos. No entanto, a negligência de certos sentimentos é característica não só da literatura soviética, mas da literatura russa em geral. A famosa frase de Leão Tolstoi, de que "todas as famílias felizes são felizes da mesma forma", caracteriza toda a literatura russa. Ou seja, os escritores russos nunca tiveram interesse em amor feliz. Mas os leitores têm. Eles querem ler não só sobre o amor trágico, não correspondido, mas também sobre o amor triunfante, vitorioso e, o que é muito importante, sensual. E nesse romance de Jorge Amado, como diz o pesquisador de sua obra Oleg Volkov, "em todo o seu decorrer soam sinos radiantes de amor ardente e puro, que traz inesgotáveis alegrias e regozijo da alma" (VOLKOV, 1970, p. 7).

Então os livros de Jorge Amado foram aceitos na Rússia por oferecerem aos leitores russos aquilo que não a literatura de seu país podia dar.

3. Além disso, as obras literárias se ajustam a outras formas de arte: adaptação para o teatro e o cinema. Por exemplo, na Rússia, há varias adaptações para teatro de Capitães da areia e Dona Flor, que mostram o enraizamento desses livros na cultura russa. Por sua vez, 
há muitas adaptações de Dostoievski no Brasil; e isso significa que seus livros tornaram-se parte da cultura brasileira.

Podemos, desse modo, concluir que qualquer obra literária, em sua gênese, pertence à literatura nacional e a uma época histórica determinada, mas, no processo de intercâmbio literário internacional, torna-se um fator efetivo em outras literaturas, apesar de, ao mesmo tempo, passar por uma grande transformação nas traduções que venha a merecer. 


\section{REFERÊNCIAS BIBLIOGRÁFICAS}

JIRMÚNSKI, V. M. Goethe v russkoi literature. Leningrado: Nauka, 1981.

KUTEISCHIKOVA, V. N. Fantazii zemli i durra. Literaturnaia Gazeta, 11 set. 1982.

NEUPOKÓEVA, I. G. Istoria vsemrnoi literaturi. Moskva: Nauka, 1976.

STÁDNIKOV, T. V. Russkii literaturnii protstss 18. veka i perevod. In: Traditsii v kontexte russkoi kulturi. Tcherepovets: Editora CGU, 2000.

VESSELÓVSKI, A. N. Izbrannie trudi. Leningrado: Khudojestvennaiz Literatura, 1939.

VOLKOV, O. Veselii i jutkii mir. In: AMADO, J. Dona Flor e seus dois maridos. Moskva: Progress, 1970. 